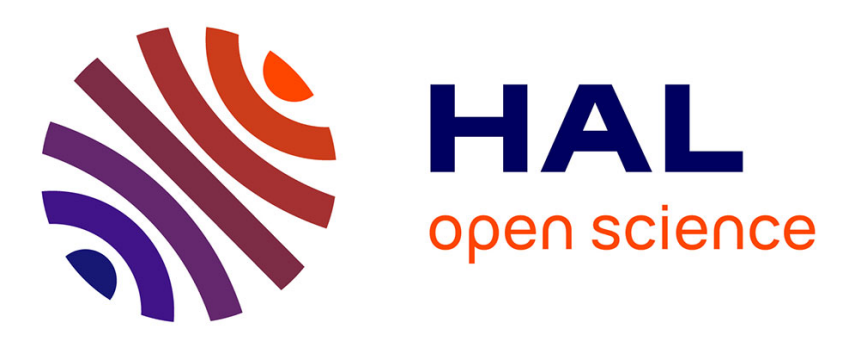

\title{
A Swedish case study on the prediction of detailed product recovery from individual stem profiles based on airborne laser scanning
}

Andreas Barth, Johan J. Möller, Lars Wilhelmsson, John Arlinger, Rikard Hedberg, Ulf Söderman

\section{To cite this version:}

Andreas Barth, Johan J. Möller, Lars Wilhelmsson, John Arlinger, Rikard Hedberg, et al.. A Swedish case study on the prediction of detailed product recovery from individual stem profiles based on airborne laser scanning. Annals of Forest Science, 2015, 72 (1), pp.47-56. 10.1007/s13595-014-04006. hal-01284162

\author{
HAL Id: hal-01284162 \\ https://hal.science/hal-01284162
}

Submitted on 7 Mar 2016

HAL is a multi-disciplinary open access archive for the deposit and dissemination of scientific research documents, whether they are published or not. The documents may come from teaching and research institutions in France or abroad, or from public or private research centers.
L'archive ouverte pluridisciplinaire HAL, est destinée au dépôt et à la diffusion de documents scientifiques de niveau recherche, publiés ou non, émanant des établissements d'enseignement et de recherche français ou étrangers, des laboratoires publics ou privés. 


\title{
A Swedish case study on the prediction of detailed product recovery from individual stem profiles based on airborne laser scanning
}

\author{
Andreas Barth • Johan J. Möller • Lars Wilhelmsson • \\ John Arlinger • Rikard Hedberg • Ulf Söderman
}

Received: 12 November 2013 / Accepted: 18 June 2014 / Published online: 13 August 2014

(C) INRA and Springer-Verlag France 2014

\begin{abstract}
- Context Improved and cost-efficient predictions of detailed product recovery from logging operations may increase efficiency and improve value chains based on modern cut-tolength harvesting (CTL).

- Aims The objective of this study was to investigate and evaluate the use of individual tree data estimates from two inventory techniques: (a) established airborne laser scanner inventory (ALS case) and (b) traditional field inventory (BAU case) for predicting product recovery in a Swedish case study. - Methods Statistics from previous harvester production files within the region were used to generate realistic levels of simulated stem defects. Bucking simulations were performed to optimise log products according to stem profiles, stem defects, and an operational price list expressing the demand of the industry customer. All simulation results at the stand level were compared to operational harvester production data that were used to provide an accurate measure of the 'true' product recovery. The total harvested area was 139 ha including 16 forest stands. Seven groups of $\log$ products were included in the analysis. The predicted versus real top
\end{abstract}

\section{Handling editor: Barry Alan Gardiner}

Contribution of the co-authors Andreas Barth and Lars Wilhelmsson: writing the paper.

Ulf Söderman, Rikard Hedberg, Johan J. Möller, John Arlinger, and Andreas Barth: data delivery.

Andreas Barth, Lars Wilhelmsson, Johan J. Möller, and John Arlinger: data analysis.

Johan J. Möller and Andreas Barth: project coordination.

A. Barth · J. J. Möller $\cdot$ L. Wilhelmsson $(\varangle) \cdot J$. Arlinger

Skogforsk - The Forestry Research Institute of Sweden, Uppsala

Science Park, SE-75183 Uppsala, Sweden

e-mail: Lars.Wilhelmsson@skogforsk.se

R. Hedberg $•$ U. Söderman

Foran Remote Sensing AB, Linköping, Sweden diameter distributions of sawlogs were evaluated using an error index to express deviations.

- Results At the stand level, the average error index values were 0.15 and 0.18 for the ALS and BAU approaches, respectively. As a consequence of an overall bias of the ALS tree lists the opposite was found at the total wood flow level, with the field-based data yielding a lower error index.

- Conclusions The volume predictions for different log product groups were slightly more accurate in the ALS case than in the BAU case.

Keywords Bucking simulation · Pre-harvest planning . Airborne laser scanning · Field inventory - Operational planning

\section{Introduction}

Improved and cost-efficient predictions of product recovery from logging may increase operational efficiency and improve value chains based on modern cut-to-length harvesting (CTL), especially when aiming for closer integration between forestry and the wood processing sector (Bengtsson et al. 1998; Moberg and Wilhelmsson 2003; Sondell and Mitchell 2004; Wilhelmsson 2005; Moberg and Nordmark 2006; Moberg et al. 2006; Wilhelmsson et al. 2011). In Sweden, log products from one harvesting object are commonly destined for a number of different customers, some or all with different specific requirements for the products. A key factor in efficient planning of the wood flow is an accurate prediction of the amount of $\log$ products as specified for different customers. In Swedish forestry, a log product is either a defectfree sawlog with certain properties such as species, length, and diameter, or a pulp log meeting species and freshness criteria. Typically, sawmill customers would accept some dimensional deviations (lengths and diameters) of delivered log products 
but commonly with a price reduction for the lower quality logs. Price matrices built on desired and undesired combinations of log diameter and lengths are used in the harvester computers to control production by diameter and length measurements, taper prediction, and operators' judgements of unacceptable stem defects into logs of optimal diameter and lengths according to the customers' demands. In similar with real production, predictions of product recovery are typically based on individual stem profiles and the same price matrices are planned to be used in the harvesting operation (Arlinger et al. 2003). Consequently, bucking simulations provide forecasts of the $\log$ product distribution in terms of $\log$ tallies including the length, diameter, volume, and value of each log product. The modern planning systems used by many Swedish forestry companies are typically built on bucking simulations based on average stand estimates at the tree species level. Full inventories of individual trees including stem diameter (Uusitalo 1997; Hansson 1999) and stem quality measurements are often regarded as being excessively timeconsuming and expensive for these purposes, and are therefore rarely performed. Yield predictions are therefore based on (objective) low-frequency sampling, subjective field inventory (Ståhl 1992; Peuhkurinen et al. 2007), or assumptions concerning the height and diameter distributions of the individual trees. To produce virtual stems for the bucking simulations, assumptions concerning stem taper and frequencies of stem defects within the stands are added to the analyses. Over the last few decades, airborne laser scanning (ALS) systems have enabled foresters to obtain accurate volume estimates for stands with a standard deviation (SD) typically between 8 and $14 \%$ (Næsset 2007) and with a high spatial resolution (Sängstuvall et al. 2012). Methods have also been developed for estimating diameter distributions, based on both low(Gobakken and Næsset 2005; Maltamo et al. 2009) and high-resolution ALS data (Holmgren et al. 2003; Persson et al. 2002). In addition, Holmgren et al. (2012) have presented an ALS-based method that uses CTL-harvester measurements to predict stem taper values for non-harvested trees. Barth and Holmgren (2013) found that this method was also useful for predicting product recovery when the estimated diameter distribution was combined with local predictions of stem taper information. However, the use of individual stem CTL-harvester measurements in ALS-based inventories requires the geographic position of the harvester head, which is not currently possible on an operational scale. Peuhkurinen et al. (2008) were successful in estimating species-specific diameter distributions by combining low-resolution ALS and aerial photographs. However, the predictions of product recoveries were poor. One reason might be the lack of local information on tree quality attributes. Furthermore, Peuhkurinen et al. (2007) compared a range of pre-harvest inventory methods including methods that are currently available for use in practical forestry. Both ALS-based and field- based inventory methods were considered and the former were found to have more potential for predicting diameter distributions, at both the individual tree and log levels. However, the methods were only applied to two stands, and only geometric data on the trees were considered. Operational planning tools that generate tree tallies (stem data) for use in bucking simulations are already used in practical forestry, and forest data suppliers are already able to deliver tree-level data based on ALS. As part of the Flexwood project (www. flexwood-eu.org), methods for predicting product recovery were further developed and implemented in commercial systems. A commercial ALS-based survey of an area covering 16,500 ha that provided information on individual trees was then conducted to provide input data for use with operational planning tools. This made it possible to evaluate the implemented methods in a similar way to that used by Peuhkurinen et al. (2007) but with a much larger data set. The impact of stem defects is an important factor that affects the outcomes of practical bucking. Consequently, it is important to consider also in simulations. Regardless of the method used to generate the inventory, data from CTL harvesters can be used to generate standardised statistics for stem defects at the single tree level. In the Swedish case, stem defects typically were caused by butt rot, sweeps, unacceptable spike knots, and deeper scars causing downgrading of sawlogs.

The objective of this study was to evaluate the utility of individual tree data generated by (a) airborne laser scanning (the ALS approach) and (b) a traditional field inventory (the BAU approach) for predicting the real product recovery in a practical case where it is necessary to account for downgrading due to stem defects. The BAU case represents 'business as usual' in modern Swedish forestry, while the ALS-based approach was selected to evaluate the potential for using individual tree data obtained through ALS-based inventories. Also, the ALS approach represents a method that has been developed in recent years and is commercially operational in Swedish forestry. The two methods were evaluated using the actual log production recorded in the standardised (StanForD 2010) harvester production file as a reference.

\section{Material and methods}

Forest data from two inventory techniques, ALS and BAU, were evaluated in this work. In the ALS approach, the inventory data were derived from ALS remote sensing measurements in conjunction with field measurements from sample plots. An established commercial method for ALS inventory of single trees was used. The BAU approach was based on subjective observations made in the field supported by existing plans from earlier assessments. The planning in this case was conducted by experienced planners and represents best practice in the implementation of the BAU routines used 
at many Swedish forest companies today. The tree tallies from the ALS and BAU approaches were used, separately, to describe the forest stands, perform bucking simulations, and predict product recovery. Finally, all of the simulation results at the stand level were compared to the data in the corresponding harvester production files, which were used as reference values representing the realised product recovery. The workflow of the material and methods used in the study is shown in Fig. 1.

The study area is located in Uppsala County approximately $100 \mathrm{~km}$ north of Stockholm, Sweden (lat. $60^{\circ} 12^{\prime} \mathrm{N}$, long. $18^{\circ}$ $\left.00^{\prime} \mathrm{E}\right)$. The landscape in this region is essentially flat with minor and mostly smooth variation in elevation. The studied forest land consists of managed boreal forest stands dominated by mixed stands of Scots pine (Pinus sylvestris) and Norway spruce (Picea abies). The main deciduous trees present are birch (Betula spp.) and aspen (Populus tremula). The total harvested area was 139 ha and featured 16 forest stands. The forest owner is Bergvik Skog AB, which owns about 2 million hectares of productive forest land in central Sweden. BillerudKorsnäs $\mathrm{AB}$ purchases standing timber from Bergvik Skog AB (and many other forest owners) and was responsible for the harvesting operations. Approximately half of the wood volume harvested by BillerudKorsnäs is delivered to its own pulp and paper mills, with the other half being sold and delivered to at least 20 external industries, mainly sawmills and energy plants.

\subsection{ALS inventory}

ALS-based tree inventory is an established commercial method for obtaining individual tree data. The method including

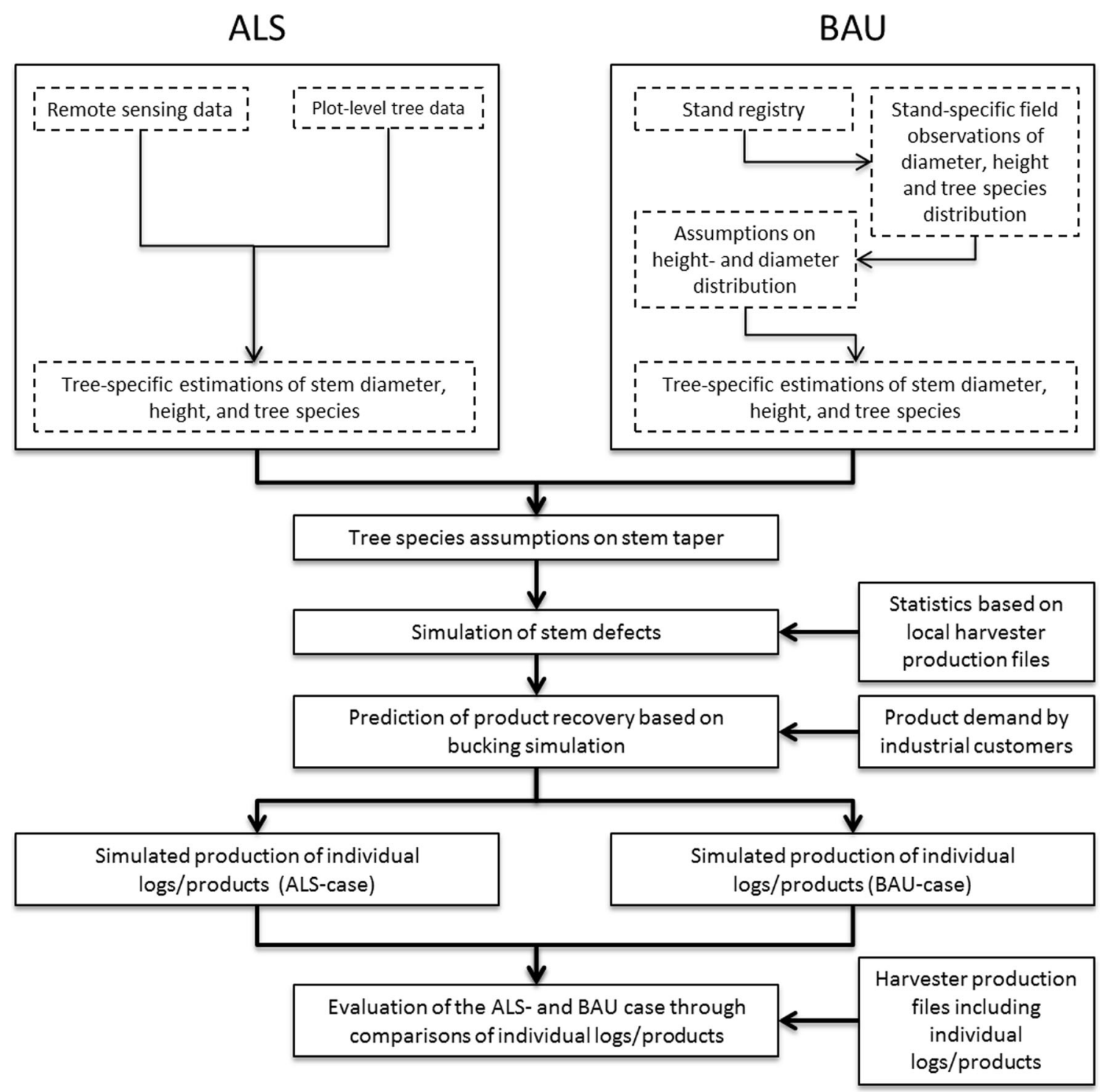

Fig. 1 An overview of the material and methods that were used in the study to predict the product recovery including the input data from the ALS and BAU approaches 
processing techniques used was developed and implemented based on research results such as Holmgren and Persson (2008), Kaartinen and Hyyppä (2008), and Persson et al. (2002). The following provides a short overview of the inventory for this study. The airborne laser scanning and hyperspectral image capture were performed on September 30 and October 1, 2010. The sensor instruments were carried by an Observer P68 fixed-wing twin engine aircraft flying approximately $700 \mathrm{~m}$ above ground. The laser data were acquired using the Optech ALTM Gemini laser scanner with its field of view set to $\pm 11^{\circ}$ of nadir. The scanner frequency was set to $70 \mathrm{~Hz}$ and the laser pulse repetition frequency to $125 \mathrm{kHz}$. The instrument was set to record up to four range measurements, including first, second, third, and last of the laser pulse returns. This yielded a laser data set with an average point density of 9 points per square metre on the ground in open areas. Hyperspectral images were acquired using an ITRES CASI-1500 hyperspectral image line scanner. The scanner was set to collect 13 spectral bands and the resulting images had an average pixel size on the ground of $0.35 \mathrm{~m}$. During the post-processing of the image data, orthophotos were produced using a canopy surface model based on the laser data. Field data were recorded for 115 sample plots within the survey area. Each sample plot was circular with a radius of $8.0 \mathrm{~m}$. The position and DBH (stem diameter at breast height $=1.3 \mathrm{~m}$ ) was measured and the tree species was determined for each tree in each plot with DBH $>10 \mathrm{~cm}$.

In brief, the tree data for the standing forest were extracted as follows. First, single trees were identified by the detection and delineation of individual tree crown segments using ALS data. Second, the trees in the field plots were linked to the corresponding tree crown segments found in the first step. Third, the tree crown segments were combined with the image data, and spectral responses for the trees were extracted. Fourth, a species classifier was established using spectral responses and the field data. This classifier was then used to classify all the identified trees. Fifth, DBH was computed for each identified tree using regression functions. Finally, a complete single tree data set was compiled, formatted, and saved.

The method for delineating individual tree crown segments is based on the idea of finding local maxima corresponding to tree tops in a canopy elevation model. The method involves three main steps: (1) the creation of a digital canopy surface model (DCM), (2) filtering the DCM with different levels of smoothing, and (3) using the smoothed surfaces to detect local maxima and delineate the tree crowns. In this work, the DCM was created as the difference between a digital surface model (DSM) and a digital terrain model (DTM). The DCM was then smoothed to make it more likely that a single tree would have a single height maximum. This smoothing was performed by filtering the DCM using a number of different 2D Gaussian filters. This resulted in a set of models that were used as inputs for the identification of individual trees and to delineate tree crown segments. The position, height, and crown area of each tree were also measured.

In order to differentiate between spruce, pine, and broadleaved trees, species classification was performed using the spectral responses in the hyperspectral digital images. In brief, the spectral response corresponding to each individual tree crown was extracted from the images and feature variables for the classification were computed. The classification was then performed using a maximum likelihood classifier. To estimate DBH, functions based on measured tree heights and crown segment areas were created using regression analysis. One function for each species was created. The function was then applied to all identified trees of that species. To estimate volume, Näslund's (1947) volume functions for southern Sweden were used for each of the three tree species, pine, spruce, and birch. The independent variables were DBH and height.

\subsection{BAU inventory}

The BAU case was based on stand average estimates of DBH, volume, height, and total number of stems. Stands available for harvesting were selected based on the information in the forest owner's stand registry. All stands were surveyed by experienced planners from the forest company, who performed field observations that were supported by information from the existing stand registry. These harvest planning surveys were used as a source of data for subjective assessments of the stands' basal area-weighted DBH and tree height per species (pine, spruce, broadleaf) as well as the number of stems per species and hectare. Based on the stand averages, general functions were used to generate a list of single trees to serve as inputs for the bucking simulation. A beta distribution was used to estimate DBH distributions (Nilsson 1976), giving a predicted number of stems of each diameter class within each stand. The parameters used for the beta distribution were similar to those incorporated into Skogforsk's 'Yield (Utbyte)' software (Arlinger 1997). The beta distribution is defined in Eq. 1.

$B(m, n)=\int_{0}^{1} x^{m-1}(1-x)^{n-1} d x \quad m, n>0$

The parameter $m$ was determined as $m=0.5+0.10(d-6)$ for pine and birch, respectively, and by $m=0.3+0.08(d-6)$ for spruce. The parameter $n$ was determined as $n=$ $m((b-a) /(d-a)-1)$ for all species. The beta distribution is defined in an interval between $a$ and $b$; it was transformed to a diameter distribution in the interval where $a$ corresponded 
with $0.4 d$ and $b$ corresponded with $1.7 d$, where $d$ is the average diameter. Species and stand-specific tree height functions based on Ollas (1980) were determined for basal areaweighted height and DBH within each species and stand. Finally, the heights of trees belonging to individual diameter classes for each species and stand were predicted using the tree height functions and applied to the tree tallies.

\subsection{Description of stem defects based on harvester data}

Harvester production files were collected from eight previously harvested forest stands within the study area in order to obtain statistics on the frequencies of stem defects. Butt rot, sweeps, oversized branches (spike knots), and deep scars are examples of stem defects not accepted in sawlogs. Thus, parts of stems qualified for sawlog dimensions but with stem defects are downgraded by the harvester operator to pulp- or fuelwood. Statistics on defects that necessitated manual cutting by the harvester operator and resulted in a shortened log length were also collected. Table 1 shows statistics from harvester production files for stand average parameters that could not be measured by laser scanning or ordinary sample plot calipering. These statistics were used as inputs to account for downgrading during the bucking simulations, based on input tree data for the ALS and BAU cases. The stem defect statistics were implemented at the single tree level. For each stem defect, frequencies, height range, and length were determined.

\subsection{Product recovery by bucking simulation}

Predicted product recoveries were analysed using the bucking simulation software package 'Aptan' (Arlinger et al. 2003), which simulates the production of a CTL harvester. Bucking simulation and real harvesting were performed based on the same price matrices. In total, seven product groups were included in the analyses. Sawlogs, small sawlogs (top diameter $>15 \mathrm{~cm}$ ), and pulpwood were the product groups produced from pine and spruce. Broadleaved trees were exclusively bucked into pulp wood. For each of the two inventory data sets, stem files were generated and used to describe the standing trees, including stem defects and stem taper. Lists of trees in each stand were obtained from the ALS and BAU data sets. These lists included information on height, DBH, and species for each tree as an input to generate individual stem profiles using functions according to Edgren and Nylinder (1949). The function system provides a combination of three logarithmic expressions controlled by a set of parameters which are determined by a form factor to describe individual stem shapes on a relative scale. Each function describes different parts of the stem and has the same slope at the intersection. The absolute estimates/measures of individual tree $\mathrm{DBH}$ and heights are then multiplied by the relative diameter and height to achieve absolute values. Form factors of 0.69 and 0.66 were used for pine and spruce, respectively. These functions are commonly used in Swedish software solutions, like the reference and development software Skogforsk TimAn. A complete description of the functions and parameters is extensive and requires several pages; however, all are given in Edgren and Nylinder (1949). The Aptan bucking simulation provided predictions of individual logs including volumes under bark for each of the seven product groups.

\subsection{Evaluation and statistical analyses}

Harvester production data were assembled from final fellings in 16 forest stands with a total area of 139.3 ha. The total harvested volume was $37,636 \mathrm{~m}^{3}$ sub, and the number of harvested trees was approximately 77,000. The harvesters measured the diameter, length, and volume of each individual $\log$ and these quantities were recorded together with the product name, tree species, and the tree's GPS coordinates in the standardised StanFord 2010 harvester production file (hpr). The production recorded by the harvesters was then compared to the product recovery predictions generated using the data for the ALS and BAU cases. The borders of the harvested areas were determined based on the GPS data from the harvesters and was verified manually using handheld GPS devices in most stands. Mean deviations (bias), standard deviations, and root-mean-square error (RMSE) values were calculated for the residuals between the true production and predicted product recovery values. To express deviations between predicted and observed distributions on diameter classes, an error index was proposed by Reynolds et al. (1988). This approach has been applied by several authors (e.g. Gobakken and Næsset 2005; Bollandsås and Næsset 2007; Holmgren et al. 2012). To analyse the distribution of

Table 1 Statistics on stem defects based on harvester production files collected from previous loggings within the studied region

\begin{tabular}{|c|c|c|c|c|c|c|}
\hline Species & Number of stands & $\begin{array}{l}\text { Average stem size } \\
\left(\mathrm{m}^{3} \mathrm{sub}\right)\end{array}$ & $\begin{array}{l}\text { Saw log yield } \\
\text { (\% of volume) }\end{array}$ & $\begin{array}{l}\text { Stem defects (downgraded logs) } \\
\text { (\% of volume) }\end{array}$ & $\begin{array}{l}\text { Stem defects (downgraded butt logs) } \\
\text { (\% of volume) }\end{array}$ & $\begin{array}{l}\text { Total volume } \\
\left(\mathrm{m}^{3} \mathrm{sub}\right)\end{array}$ \\
\hline Pine & 9 & 0.68 & 79.5 & 9.1 & 3.7 & 19,574 \\
\hline Spruce & 9 & 0.40 & 63.6 & 14.6 & 10.8 & 13,052 \\
\hline
\end{tabular}


logs across diameter classes in this study, such an error index (Eq. 1) was derived for both the stand level distributions and the overall distribution including all 16 stands. The error indices were then used to summarise the deviation per diameter class divided by the total number of logs and compare the performances of the ALS and BAU methods. The logs were separated into 2-cm classes according to their top diameters. Error indices were then calculated for each diameter class using the expression shown in Eq. 2. Here, $P$ is the predicted number of logs per diameter class and $O$ is the observed number of logs per diameter class. $N$ is the total number of observed logs for all diameter classes and $M$ is the number of diameter classes.

$E I=\frac{1}{N} \sum_{t=1}^{M}\left|P_{t}-O_{t}\right|$

Both forest data and product recovery evaluations were performed for each of the 16 stands. Data on individual logs from the same tree were summed to determine its volume. Tree heights were estimated based on the summed lengths of the logs, using the functions developed by Kiljunen (2002) to estimate the height of the tree top. The volumes of the remaining tree tops above merchantable log dimensions were estimated as the volume of a cone. The statistical strength of the differences between the ALS and BAU cases were tested for four groups of top diameter classes (cm), (1) $7 \leq D_{\text {top }}<11$, (2) $11 \leq D_{\text {top }}<15$, (3) $15 \leq D_{\text {top }}<33$, (4) $D_{\text {top }} \geq 33$ of all logs from pine and spruce. This was performed as a $t$ test of significant differences in total volume per diameter class between paired and correlated variables using SAS proc TTEST and the PAIRED statement $(p=0.05)$.

\section{Results}

Individual tree data for the standing trees based on the ALS and BAU cases were evaluated at the stand level. Generally, the ALS case provided a lower RMSE than the BAU case (Table 2). However, the volume functions for standing trees developed by Näslund (1947) gave an overestimated volume of $5.7 \%$ (bias) whereas the BAU case resulted in a minor bias of $-1.2 \%$. The SD values for the ALS and BAU cases were 7.8 and $13.3 \%$, respectively, indicating that the ALS approach was more precise.

Comparative analyses of the different products are presented in Fig. 2, which compares results of the true log production from the harvesters to predictions based on the ALS and BAU cases. The predictions for the ALS case overestimated the total $\log$ volume by $5.2 \%$ while those for the BAU case underestimated the total log volume by $0.4 \%$. However, the ALS case yielded more accurate predictions of the total volume for five of the seven product groups at the flow level when comparing all volumes for the total harvested area. The predictions based on the ALS data set were also more accurate than the BAU predictions regarding the frequencies of volumes per product group from both pine and spruce (Figs. 3 and 4).

The ALS predictions tended to be more accurate for the numbers of small- and medium-diameter logs than the BAU case (Fig. 5). However, they also tended to give overestimates for the intermediate log diameter classes whereas the opposite was observed for the BAU case.

The results of the statistical analyses for the grouped diameter classes are presented in Table 3. Paired $t$ tests demonstrated often significant differences between the ALS and BAU volume predictions for pine but only occasionally for spruce. The ALS predictions for three of the four pine diameter groups were significantly more accurate than the BAU predictions. However, the BAU predictions appeared to be significantly better for one of four spruce diameter groups, whereas no significant differences between the methods were detected for the other diameter groups. In one of the groups, the $t$ test indicates significance between the BAU and the ALS estimates. However, since one of the methods gives an overestimation while the other an underestimation, it is not clear if any of the estimation is significantly better than the other. In consequence with the results regarding the total number of logs, the ALS approach overestimated the volume of intermediate-sized logs and underestimated that of large logs for both pine and spruce. Results from the BAU approach suggested these tendencies were less pronounced. However,
Table 2 Evaluation of stand data for the 16 stands based on the ALS and BAU case using harvester measurements as a reference

\begin{tabular}{|c|c|c|c|c|c|c|}
\hline \multirow[t]{2}{*}{ Property } & \multicolumn{3}{|l|}{ ALS } & \multicolumn{3}{|l|}{ BAU } \\
\hline & Bias $(\%)$ & $\mathrm{SD}(\%)$ & RMSE (\%) & Bias (\%) & $\mathrm{SD}(\%)$ & RMSE (\%) \\
\hline Basal area & 0.6 & 9.8 & 9.9 & -2.7 & 12.5 & 12.8 \\
\hline Diameter & -3.8 & 3.4 & 5.1 & -1.9 & 6.4 & 6.6 \\
\hline Number of trees & 3.8 & 14.7 & 15.2 & -7.6 & 15.9 & 17.6 \\
\hline Volume & 5.7 & 7.8 & 9.6 & -1.2 & 13.3 & 13.4 \\
\hline Height & 0.6 & $2.5 \%$ & 2.6 & & & \\
\hline
\end{tabular}




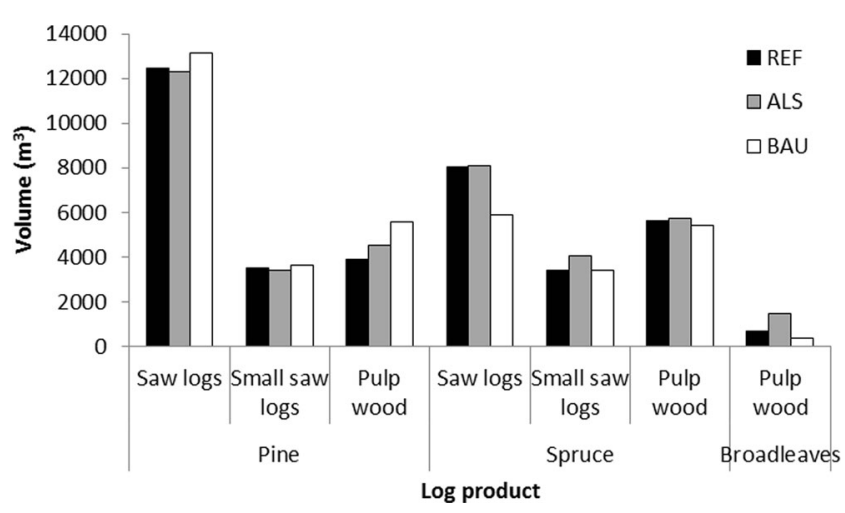

Fig. 2 Predictions of volume $\left(\mathrm{m}^{3}\right)$ per product group based on ALS and BAU input data compared to reference data (REF) from real production as recorded in the harvester production file. Sawlogs are logs with a top diameter of more than $15 \mathrm{~cm}$ and small sawlogs are logs with a top diameter of less than $15 \mathrm{~cm}$

in the BAU approach, the distribution on species was biased resulting in an overestimation of pine volumes and an underestimation of spruce volumes (Fig. 6). Overall, the standard deviations for the ALS predictions were lower than those for the BAU predictions.

The results of the error index analyses are presented in Table 4. These indicate how well the distributions based on the ALS and BAU approaches fit the reference distribution. The error index is also presented (Fig. 7) on a stand-by-stand basis for the two approaches (ALS and BAU). In the BAU case, the differences within stands were generally higher than in the ALS case. However, the ALS case produced relatively high error index values for some stands. At the wood flow level, comparing the total volumes from all stands, the error index results showed that the ALS approach yielded better performance when the small diameter classes were considered, whereas the BAU approach was more accurate when considering only logs with diameters of more than $15 \mathrm{~cm}$ (Table 3). At the stand level, the ALS approach generated

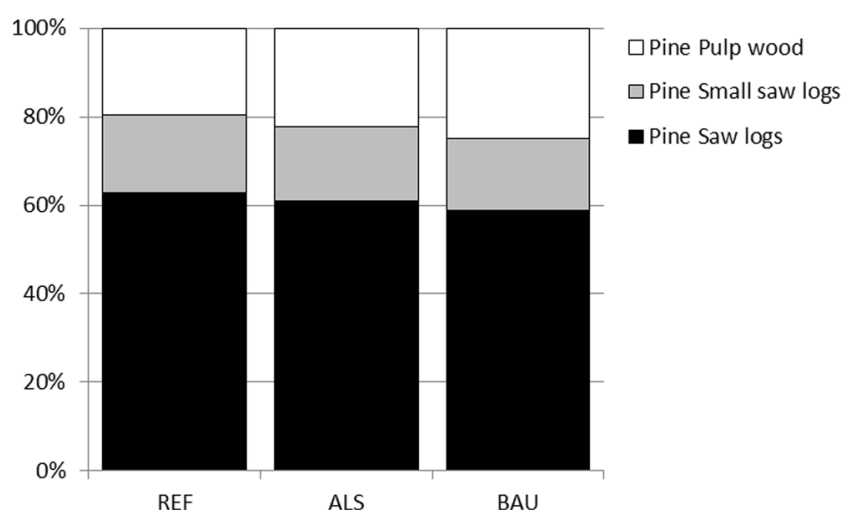

Fig. 3 Volume predictions of Scots pine products based on ALS and BAU input data compared to reference data (REF) from real production as recorded in the harvester production file. Sawlogs are logs with a top diameter of more than $15 \mathrm{~cm}$ and small sawlogs are logs with a top diameter of less than $15 \mathrm{~cm}$

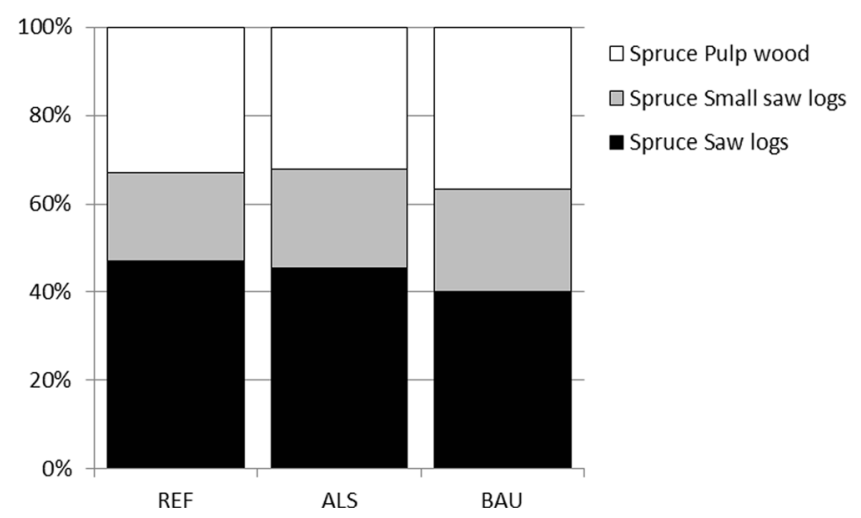

Fig. 4 Volume predictions for Norway spruce products based on ALS and BAU input data compared to reference data (REF) from real production as recorded in the harvester production file. Small sawlogs are logs with a top diameter of less than $15 \mathrm{~cm}$

better predictions of the logs' diameter distributions for all diameter classes.

\section{Discussion and conclusions}

The results presented herein show that ALS-based inventory data can improve the prediction of product recovery. However, ALS data must be complemented with information on stem defects and stem taper. Such data can be obtained from CTL harvesters. To our knowledge, this is the first study in which the results of bucking simulations based on ALS data are compared to actual production data from harvesters. Both Peuhkurinen et al. (2007) and Barth and Holmgren (2013) used stem measurements from harvesters as a source of reference data but then used bucking simulations to generate reference data for the different products. These previous studies therefore failed to consider stem defects, which are often very important in practical forestry. However, in keeping with the results of the previous studies, the ALS-based approach

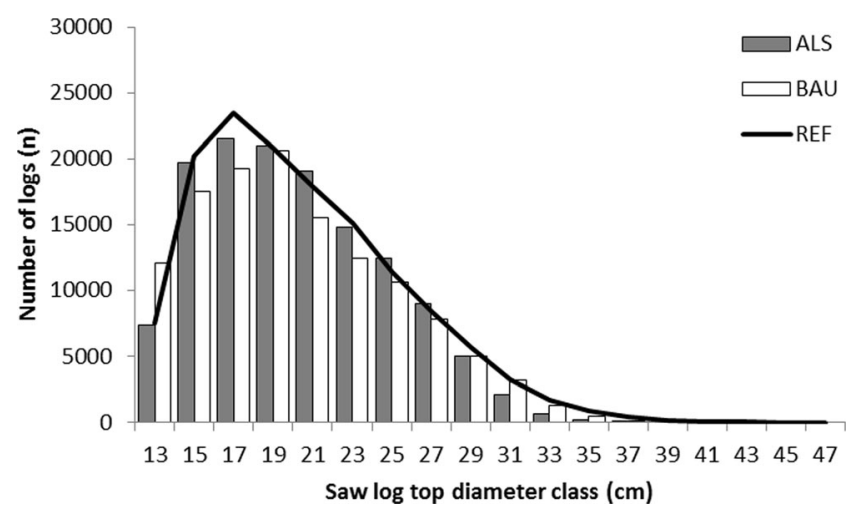

Fig. 5 The predicted sawlog volume distribution based on ALS and BAU input data compared to reference data (REF) from real production as recorded in the harvester production file. Both small and large sawlogs from Scots pine and Norway spruce are included in the data 
Table 3 Bias, SD, RMSE, and Student's $t$ test results for four groups of diameter classes for pine and spruce

\begin{tabular}{|c|c|c|c|c|c|c|c|c|c|}
\hline \multicolumn{2}{|c|}{ Log diameter $(\mathrm{cm})$} & \multirow[t]{2}{*}{$N$} & \multicolumn{2}{|c|}{$\operatorname{BIAS}\left(\mathrm{m}^{3}\right)$} & \multicolumn{2}{|c|}{$\mathrm{SD}\left(\mathrm{m}^{3}\right)$} & \multicolumn{2}{|c|}{$\operatorname{RMSE}\left(\mathrm{m}^{3}\right)$} & \multirow{2}{*}{$\begin{array}{l}t \text { test } \\
\operatorname{Pr}>\mid t\end{array}$} \\
\hline & & & ALS & BAU & ALS & BAU & ALS & BAU & \\
\hline \multirow[t]{4}{*}{ Pine } & $<11$ & 48 & 1.5 & 6.2 & 8.3 & 13.3 & 8.5 & 14.7 & 0.010 \\
\hline & $11-15$ & 32 & -2.0 & 15.2 & 23.0 & 38.7 & 23.0 & 41.5 & 0.018 \\
\hline & $15-33$ & 160 & 4.5 & 12.1 & 44.0 & 44.8 & 44.3 & 46.4 & 0.045 \\
\hline & $\geq 33$ & 65 & -5.9 & -3.6 & 10.0 & 7.6 & 11.6 & 8.4 & 0.075 \\
\hline \multirow[t]{4}{*}{ Spruce } & $<11$ & 48 & -9.3 & -4.4 & 23.3 & 19.7 & 25.1 & 20.2 & 0.011 \\
\hline & $11-15$ & 32 & 6.6 & 9.8 & 23.0 & 29.2 & 24.0 & 30.8 & 0.467 \\
\hline & $15-33$ & 160 & 10.8 & -12.0 & 47.5 & 45.3 & 48.7 & 46.9 & 0.000 \\
\hline & $\geq 33$ & 98 & -7.1 & -5.7 & 12.1 & 15.7 & 14.1 & 16.7 & 0.162 \\
\hline
\end{tabular}

gave better predictions of product recovery, especially at the stand level. One advantage of being able to more accurately predict product recovery for individual stands is that it becomes possible to adjust the flow of timber by selecting which stand to harvest. The low-resolution data generated by the BAU approach provided reasonably good predictions of the total wood flow but provided more limited information on factors such as diameter distributions at the stand level.
The volume estimates generated by the ALS approach were generally high even though other properties such as basal areas, tree heights, and number of stems were accurately estimated. The use of Näslund (1947) simple volume functions clearly induced biased volume estimates for standing trees. The use of taper functions by Edgren and Nylinder (1949) for estimating shape and volume of processed stems and $\operatorname{logs}$ is also important for achieving accurate predictions
Pine

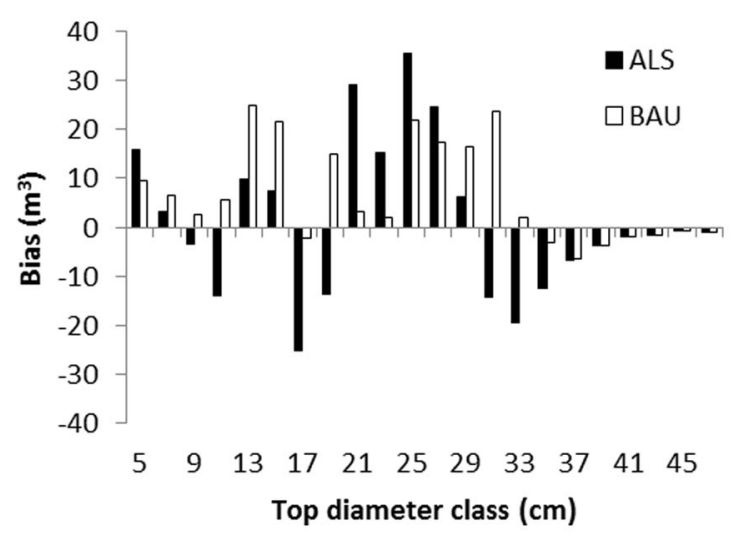

Pine

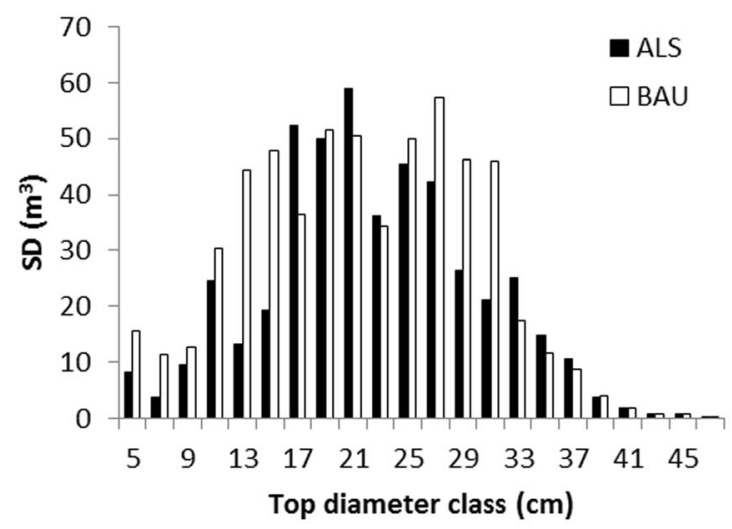

\section{Spruce}

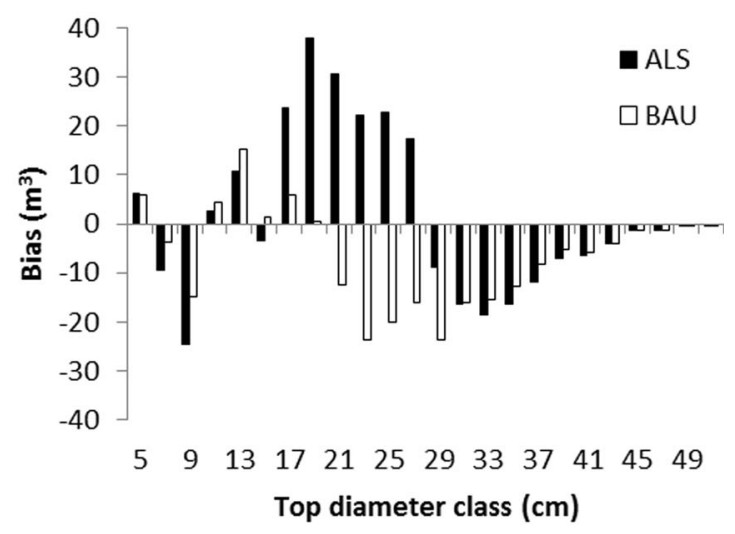

Spruce

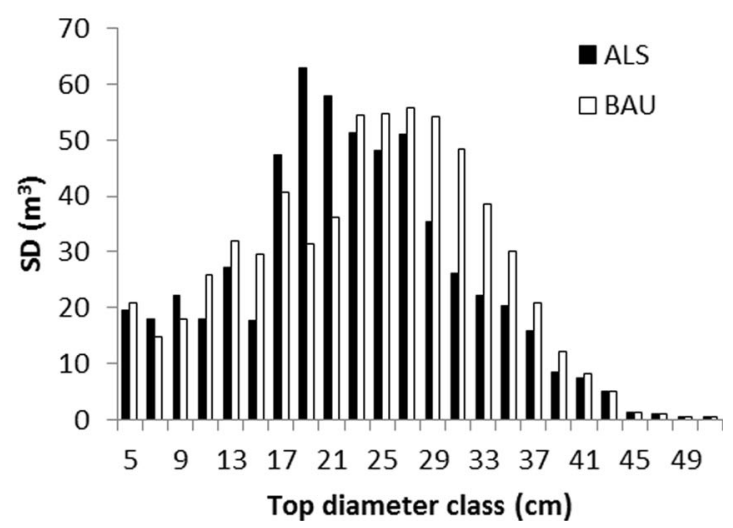

Fig. 6 Evaluation of accuracy per log diameter class (bias and SD) at the stand level. Results for each Scots pine and Norway spruce log diameter class 
Table 4 Error index values for the log diameter distribution (based on 2$\mathrm{cm}$ diameter classes) for the 16 stands

\begin{tabular}{llllll}
\hline & \multicolumn{2}{l}{ All diameter classes } & & \multicolumn{2}{l}{ Diameter class $\geq 15 \mathrm{~cm}$} \\
\cline { 2 - 3 } \cline { 5 - 6 } \cline { 5 - 6 } & ALS & BAU & & ALS & BAU \\
\hline Stand level & 0.34 & 0.44 & & 0.15 & 0.18 \\
Flow (landscape) & 0.26 & 0.30 & & 0.11 & 0.08 \\
\hline
\end{tabular}

of the product recovery. Näslund (1947) volume functions operate with fixed stem taper while Edgren and Nylinder (1949) include a form factor that improves taper flexibility of the function. When comparing the results from Näslund functions with functions developed on the basis of the actual harvested trees, the bias was decreased from 6.2 to $1.9 \%$. In Edgren and Nylinder's functions, the stem taper for a given tree DBH and total height can be adjusted by a form factor. This form factor was set to 0.66 for all spruce stems and 0.69 for all pine stems at the bucking simulation of trees within the study area. These setting of form factors were based on prior practice. However, in an indicative analysis of the harvested trees in one of the harvested stands, the total volume of spruce stems became correct in comparison with the harvester production file when a form factor of 0.60 was applied. It is therefore possible (not proven) that the overestimation of the total stem volume was due to an underestimation of the actual stem taper. Another crucial factor to consider when estimating the stem volumes is the size of the total harvested area. Area values were not considered directly in this work, since all of the evaluations were performed for the actual harvested areas. Most stem defects cannot be predicted based on ALS data only. However, it is hard to predict the full range of stem defects that necessitate the downgrading of sawlogs in Scandinavian forests even when performing field inventories. One of the most common causes of downgrading in many areas is wood decay that cannot be seen from the outside. This study has, however, demonstrated that stem defects can be predicted using high-resolution data acquired by CTL

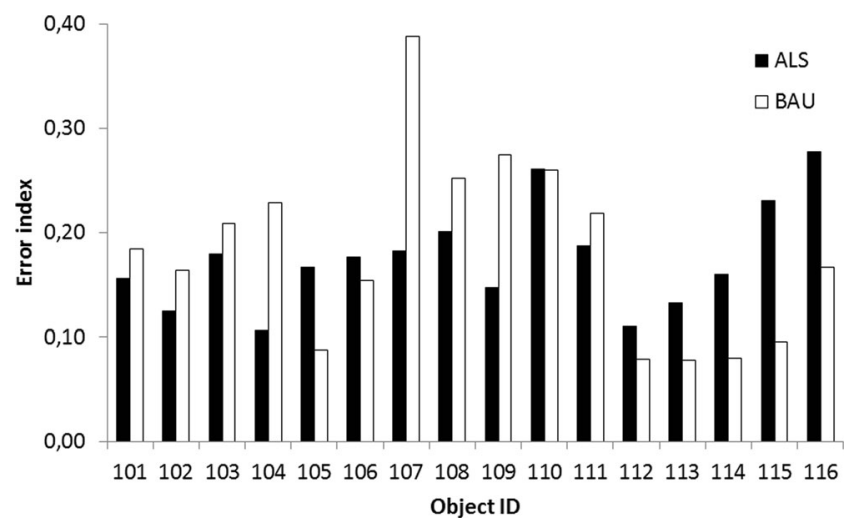

Fig. 7 Reynolds error index values for each studied stand based on the ALS and BAU approaches for all log diameter classes in excess of $15 \mathrm{~cm}$ harvesters. However, the resolution of this data in combination with the ALS and BAU cases could only be applied at the species by wood flow level. In the future, it may be possible to predict part of observed differences in defects from regional and stand characteristics and to incorporate other data such as from a terrestrial laser scanner into the approach in order to provide information on sweep and the branches of individual trees.

Finally, it can be concluded that the BAU case performed well with a low bias of the total volume estimate but with some difficulties in predicting the volume at the level of individual tree species. However, the method is based on generalisations of diameter distributions, and provided that these are correctly tuned, it is expected to perform well at the total production level, i.e. the wood flow. Also, the ALS case performed well except for the bias in total volume which seems to be an effect of biased volume functions (Näslund 1947) and insufficient knowledge on stem taper (Edgren and Nylinder 1949). However, because the ALS method used is based on actual measurements of individual tree heights and functions for estimating individual tree diameters, it has a larger potential for further development based on increased accuracy and reduced bias. Better knowledge and systematic use of information from previous harvesting stands can improve the prediction of stem taper, volume, and stem defects. Furthermore, algorithms for minimising bias at the flow level can be developed from large scale production data.

Acknowledgments BillerudKorsnäs and Bergvik Skog are acknowledged for providing forest data. Ingemar Gillgren (Bergvik skog), Göran Andersson, and Lars Ohlin (both BillerudKorsnäs) all provided vital support that made this project possible. The authors also thank the personnel and harvesting entrepreneurs who carried out the logging at the Uppland site (BillerudKorsnäs) for their assistance in recording and supplying data. Additional thanks are due to Hans Eskilsson (CGI), who provided the diameter distributions for the BAU case and to Magnus Eriksson and Per Knutsson (both CGI) for supporting and participating in the project planning. Ulf Söderman and Rikard Hedberg at Foran Remote Sensing AB delivered the ALS data and contributed to the project planning and the descriptions of the ALS case. All analyses were performed and all conclusions were drawn by the authors from Skogforsk.

Funding This study was a part of the Flexwood project, Flexible Wood Supply Chain and partly financed by the European Union 7th Framework programme and Skogforsk. The data acquisition by remote sensing and harvesting was financed by Bergvik Skog, BillerudKorsnäs, CGI, Foran Remote Sensing, and Skogforsk, respectively.

\section{References}

Arlinger J (1997) SkogForsk Yield — a program for calculations of possible levels of saw logs, pulp wood and forest fuel removals - User's Guide, version 2.0. Skogforsk, Uppsala

Arlinger J, Moberg L, Wilhelmsson, L (2003) Predictions of wood properties using bucking simulation software for harvesters. In: Nepveu G (ed) Proceedings from the fourth meeting. IUFRO Wp 
5.01-04 "Connection between forest resources and wood quality: modelling approaches and simulation software". Fourth Workshop. Hot Springs 2002. INRA, Nancy

Barth A, Holmgren J (2013) Stem taper estimates based on airborne laser scanning and CTL harvester measurements for pre-harvest planning. Int J Forest Eng 24:161-169

Bengtsson K, Björklund L, Wennerholm H (1998) Value optimised wood utilisation - a study of the prerequisites for increased profitability within the small-scale private forestry. In: Department of Forest Industry Market Studies (ed) In Swedish with English summary. Swedish University of Agricultural Sciences, Uppsala, p 86, Report 50

Bollandsås OM, Næsset E (2007) Estimating percentile-based diameter distributions in uneven-sized Norway spruce stands using airborne laser scanner data. Scand J Forest Res 22:33-47

Edgren V, Nylinder P (1949) Functions and tables for computing taper and form quotient inside bark for pine and spruce in northern and southern Sweden. Meddelanden från Statens Skogsforskningsinstitut 38:7, In Swedish with English summary

Gobakken T, Næsset E (2005). Weibull and percentile models for lidarbased estimation of basal area distribution.Scandinavian Journal of Forest Research, 20:490-502.

Hansson F (1999) Inventering före avverkning - metodval och resursåtgång. Resultat 15. Skogforsk., Uppsala (In Swedish with English summary)

Holmgren J, Persson $\AA$ (2008) Identifying species of individual trees using airborne laser scanner. Remote Sens Environ 90:415-423

Holmgren J, Nilsson M, Olsson H (2003) Estimation of tree height and stem volume on plots using airborne laser scanning. Forest Sci 49419-428

Holmgren J, Barth A, Larsson H, Olsson H (2012) Prediction of stem attributes by combining airborne laser scanning and measurements from harvesters. Silva Fenn 46:227-239

Kaartinen H, Hyyppä J (2008) EuroSDR/ISPRS Project, Commission II "Tree Extraction"; Final Report; Official Publication no. 53; EuroSDR (European Spatial Data Research): Dublin

Kiljunen N (2002) Estimating dry mass of logging residues from final cuttings using a harvester data management system. Int J Forest Eng 13:17-25

Maltamo M, Næsset E, Bollandsås OM, Gobakken T, Packalén P (2009) Non-parametric prediction of diameter distributions using airborne laser scanner data. Scand J Forest Res 24:541-553

Moberg L, Nordmark U (2006) Predicting lumber volume and grade recovery for Scots pine stems using tree models and sawmill conversion simulation. Forest Prod J 56:68-74

Moberg L, Wilhelmsson L (2003) New tools for predicting wood properties improve utilization of pulpwood. Skogforsk, Uppsala, Results 2
Moberg L, Möller J, Sondell J (2006) Automatic selection, bucking control, and sorting of sawlogs suitable for appearance-grade sawnwood for the furniture industry. New Zeal J For Sci 36:216231

Næsset E (2007) Airborne laser scanning as a method in operational forest inventory: status of accuracy assessments accomplished in Scandinavia. Scand J Forest Res 22:433-442

Näslund M (1947) Empirical formulae and tables for determining the volume of standing trees: Scots pine, Norway spruce and birch in southern Sweden and in the whole of the country. Meddelanden från Statens Skogsforskningsinstitut 36:3, In Swedish with English summary

Nilsson G (1976) Stamfördelningar [Stem diameter distributions]. Skogsarbeten, Redogörelse $\mathrm{nr} 2$

Ollas R (1980) Nya utbytesfunktioner för träd och bestånd [New yield functions for trees and stands]. Skogsarbeten, Ekonomi nr 5

Persson Å, Holmgren J, Söderman U (2002) Detecting and measuring individual trees using airborne laser scanning. Photogramm Eng Rem S 68:925-932

Peuhkurinen J, Maltamo M, Malinen J, Pitkänen J, Packalén P (2007) Preharvest measurement of marked stands using airborne laser scanning. Forest Sci 53:653-661

Peuhkurinen J, Maltamo M, Malinen J (2008) Estimating species-specific diameter distributions and saw log recoveries of boreal forests from airborne laser scanning data and aerial photographs: a distributionbased approach. Silva Fenn 42:625-641

Reynolds MR, Burk TE, Huang WC (1988) Goodness-of-fit tests and model selection procedures for diameter distribution models. Forest Sci 34:373-399

Sängstuvall L, Gillgren I, Lindgren O, Heimdal Iversen E, Brethvad T (2012) Forest inventory using LiDAR at Bergvik Skog AB. SilviLaser 2012-16-19 September 2012 - Vancouver, Canada

Sondell J, Mitchell P (2004) Production and marketing of timber in Europe. Results from the EU-project PromotE. Skogforsk, Uppsala

Ståhl G (1992) A study on the quality of compartment-wise forest data acquired by subjective inventory methods. Department of Forest Mensuration and Management, Swedish Univ of Agric Sci, Umea, Sweden. Report 24. ISSN 0349-2133. (In Swedish with English summary)

Uusitalo J (1997) Pre-harvest measurement of pine stands for sawing production planning. Acta Forestalia Fennica 259:1-56

Wilhelmsson L (2005) Characterisation of stem, wood and fiber properties - industrial relevance. Skogforsk, Uppsala, Work Report 590

Wilhelmsson L, Arlinger J, Hannrup B, Nordström M, Øvrum A, Gjerdrum P (2011) D3.5 methods and models for relating wood properties and storage conditions to process efficiency and product quality. Skogforsk, Uppsala, Work report 750 